А. Яцишин, Р. Дмитрук, А. Гавінський Природопізнавальні та геоархеологічні маршрути... ISSN 2519-2620. Проблеми геоморфології і палеогеографії...2021. Вип. 1 (12), 155-178

УДК 910.3; DOI: 10.30970/GPC.2021.1.3462

ПРИРОДОПІЗНАВАЛЬНІ ТА ГЕОАРХЕОЛОГІЧНІ МАРШРУТИ СХІДНОЇ ЧАСТИНИ ЛЬВОВА

Андрій Яцишин ${ }^{1}$, Роман Дмитрук ${ }^{1}$, Андрій Гавінський

${ }^{1}$ Львівський національний університет імені Івана Франка, andrii.yatcyshyn@1nu.edu.ua; orcid.org/0000-0002-3114-3042;

roman.dmytruk@lnu.edu.ua; orcid.org/0000=0002-1850-3242;

${ }^{2}$ Інститут українознавства ім. І. Крип'якевича НАН України, andrham@ukr.net; orcid/0000-0002-8466-0959

Анотація. Проаналізовано геоморфологічні і геологічні особливості східної частини Львова. Розроблено нову, надзвичайно мальовничу та пізнавальну туристичну, рекреаційну і геоосвітню стежку - "Чатові скелі - Винниківське озеро - Медова печера" яка лежить на продовженні туристичного маршруту "Високий Замок-Чатові скелі”. Мальовничий рельєф, відслонення різноманітних за віком і генезисом відкладів, багаті археологічні пам'ятки, які трапляються вздовж маршруту, можуть забезпечити навчальну, освітню, пізнавальну, екологічну й естетичну функції. Археологічні пам'ятки, маловідомі широкому загалу, також надзвичайно цінні, адже ілюструють історію заселення території м. Львова, його найближчих околиць.

Здебільшого об’єкти неживої природи, розташовані вздовж маршруту, добре доступні для ознайомлення, проте сьогодні вони не користуються високою популярністю серед мешканців Львова. Це пов'язано, передусім, з відсутністю належної інфраструктури промаркованих стежок, інформаційних стендів тощо.

Антропогенний вплив на об’єкти, які розташовані вздовж пропонованого маршруту, надзвичайно різноплановий і різномасштабний. Окремі об'єкти (наприклад Чатові скелі і Медова печера) зазнають значного впливу, оскільки їх активно використовують для пішого туризму, занять з альпінізму тощо. Інші (наприклад, археологічні пам'ятки Жупан і Лисівка) практично його не зазнають. Під найбільшою загрозою, аж до повного знищення, знаходяться пам'ятки Млинівці I і II. Небезпеку для них створює активне будівництво нового спортивно-оздоровчого комплексу, розгорнутого навколо Винниківського озера. Тому існує потреба в постійному моніторингу стану цих об’єктів. 3 другої сторони згаданий комплекс в майбутньому формуватиме нові перспективи використання мальовничого рельєфу, складної геоморфологічної і геологічної будови східної частини м. Львова у рекреаційних та природопізнавальних заходах. Безсумнівно, що новий центр тяжіння, яким буде спортивнооздоровчий комплекс, сприятиме зростанню відвідуваності Винниківського лісопарку. Отож потреба в налагодженні відповідної туристичної, рекреаційної, геоосвітньої інфраструктури вздовж маршруту "Чатові скелі - Винниківське озеро - Медова печера" очевидна вже сьогодні.

Ключові слова: природопізнавальний i геоархеологічний маршрут; верхньокрейдові мергелі; неогенові піски і пісковики; леси, травертини; археологічні пам'ятки.

\title{
NATURE-LEARNING AND GEO-ARCHEOLOGICAL ROUTES OF THE EASTERN PART OF LVIV Andrii Yatsyshyn ${ }^{1}$, Roman Dmytruk ${ }^{1}$, Andrii Havinskyi ${ }^{2}$
}

(с) Яцишин Андрій, Дмитрук Роман, Гавінський Андрій, 2021. 
А. Яцишин, Р. Дмитрук, А. Гавінський Природопізнавальні та геоархеологічні маршрути...

${ }^{1}$ Ivan Franko National University of Lviv,

${ }^{2}$ I.Krypiakevych Institute of Ukrainian Studies of the National Academy of Sciences of Ukraine

Abstract. Geomorphological and geological features of the eastern part of Lviv have been analyzed. A new, extremely picturesque and informative tourist, recreational and geo-educational route has been developed, namely "Chatovi Rocks - Vynnykivske Lake -Medova Pechera", which forms an extension of "Vysokyi Zamok - Chatovi rocks" tourist route. Picturesque relief, exposure of sediments of various ages and genesis, as well as rich archeological monuments occurring along the routecan perform educational, educational, cognitive, ecological, and aesthetic functions. Archaeological memorials, little known to the general public, are extremely valuable, too, because they illustrate the history of populating the city of Lviv and its neighborhood.

Mostly inanimate objects located along the route are well accessible for exploration; however, today they are not very popular among Lviv residents. This is primarily due to the lack of proper infrastructure - marked trails, information stands, etc.

Anthropogenic impact on the objects located along the proposed route is extremely diverse and large-scale. Some sites (such as Chatovi Rocks and Medova Pechera) are affected heavily, as they are actively used for hiking, mountaineering, etc. Others (for example, Zhupan and Lysivka archeological monuments) virtually do not experience it. The monuments of Mlynivtsi I and II are exposed to the greatest threat, up to complete destruction. They are endangered due to the extensive construction of a new sports and recreation complex, deployed around Vynnykivsky Lake. The refore, the condition of these facilities needs to be monitored continuously. On the other hand, the said complex will open up new prospects for the use of picturesque relief, complex geomorphological and geological structure of the eastern part of Lviv in the future recreational and geo-educational activities. There is no doubt that the new center of attraction, created by the sports and recreation complex, will increase the attendance of Vynnykivsky Forest Park. Therefore, the need to establish appropriate tourist, recreational, geo-educational infrastructure along "Chatovi Rocks - Vynnykivske Lake - Medova Pechera" route is obvious today.

Key words: nature-learning and geo-archeological route; Upper Cretaceous marls; Neogene sands and sandstones; woods, travertines; archeological monuments.

Вступ. Країни Західної Європи, Північної Америки, які активно опікуються природоохоронними й екоосвітніми проблемами та дбають про задоволення гуманітарних потреб населення, всебічно популяризують так звані туристичні маршрути вихідного дня. Доволі затребуваними такі послуги стали в період пандемії коронавірусу COVID-19, в умовах якої: по-перше, відбулась масштабна переорієнтація туристичних потоків 3 міжнародного на внутрішній ринок; по-друге, часто єдино дозволеним органами влади різновидом відпочинку залишились відвідини зелених зон міст, їхніх найближчих околиць. В Україні спостерігаються схожі зміни у туристичній, рекреаційній галузі економіки, які вимагають розширення існуючої мережі пропонованих клієнтам рекреаційних і геоосвітніх маршрутів. Важливо, що після завершення дії усіх карантинних обмежень, зумовлених пандемією коронавірусу COVID-19, розроблені маршрути не втратять своєї затребуваності. 
А. Яцишин, Р. Дмитрук, А. Гавінський Природопізнавальні та геоархеологічні маршрути...

ISSN 2519-2620. Проблеми геоморфології і палеогеографії..2021. Вип. 1 (12), 155-178

Серед мешканців Львова та його гостей традиційно найпопулярнішим є маршрут, який пролягає від Високого Замку до Чатових скель (рис. 1).

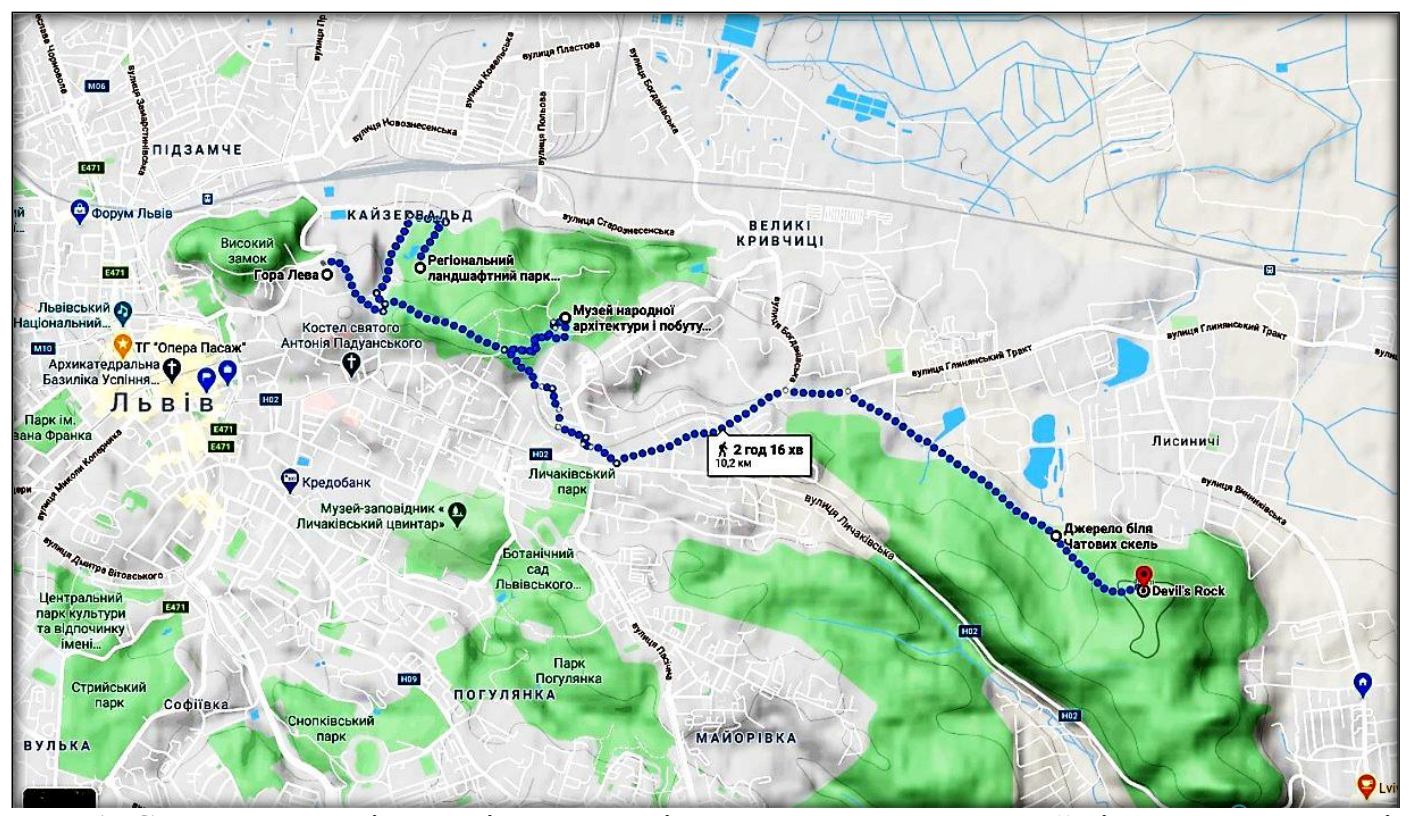

Рис. 1. Схема рекреаційного і природопізнавального маршруту “Піщана гора-Чатові скелі”(Яцишин і Дмитрук, 2020)

Fig. 1. "Pishchana Mountain - Chatovi Rocks" geo-educational and nature-learningroute diagram (Iatsyshyn and Dmytruk, 2020)

На цьому маршруті відпочивальники найчастіше відвідують г. Високий Замок, Регіональний ландшафтний парк “Знесіння”, парк “Шевченківський Гай” та розташований в його межах Музей народної архітектури i побуту імені Климентія Шептицького, а також Чатові скелі. Важливо, що цей маршрут може задовольняти не тільки історико-культурні, а й відпочинкові та природопізнавальні запити відвідувачів (Яцишин і Дмитрук, 2020). У маршруті відвідувачі мають змогу ознайомитись 3 такими типами пам'яток неживої природи, як стратиграфічні, геохронологічні, мінералого-петрографічні, палеонтологічні, геоморфологічні та мальовничі.

Рекреаційна і природопізнавальна функції численних об’єктів неживої природи, розташованих поза маршрутом Піщана гора - Чатові скелі, сьогодні висвітлені не достатньо.

Матеріали і методи досліджень. Під пам'ятками природи розуміють добре вивчені еталони природних феноменів, серед яких виокремлюють пам'ятки живої і неживої природи (Брусак і Бакун, 2011). Під пам'яткою неживої природи розуміють відслонення гірських порід різного віку (стратотипи), скупчення палеонтологічних решток, зразки типових $і$ унікальних порід і мінералів, окремі скелі та скельні 
комплекси, печери, водоспади, визначні вершини, витоки великих $i$ середніх за довжиною річок, виходи прісних і мінеральних вод, озера різного генезису тощо (Брусак і Бакун, 2011).

Досі використовують декілька розроблених класифікацій пам'яток неживої природи, які грунтуються на різних принципах. Наприклад, у довіднику-путівнику “Геологические памятники Украины” вирізняють шість типів геологічних пам'яток природи:

$\checkmark$ стратиграфічні та геохронологічні,

$\checkmark$ мінералого-петрографічні,

$\checkmark$ палеонтологічні,

$\checkmark$ тектонічні,

$\checkmark$ геоморфологічні,

$\checkmark$ мальовничі (Коротенко и др., 1985).

Класифікацію пам'яток неживої природи, засновану на предметному принципі, яка охоплює 15 типів об’єктів запропонував В. П. Грищенко з колегами (Грищенко та ін., 1995).

Генетичну класифікацію пам'яток рельєфу, розробив Е. Палієнко. Спираючись на неї, автор виділив 13 груп генетично однорідних форм рельєфу (Палієнко, 1997).

Автори В. Брусак та Ю. Зінько геологічні об’єкти пропонують поділяти на стратиграфічні, мінералого-петрографічні, палеонтологічні, тектонічні, а геоморфологічні - на морфогенетичні (морфоструктурні і морфоскульптурні), вікові (реліктові та сучасні) і пейзажні (Брусак і Зінько, 1995).

Отже, різні класифікації пам'яток неживої природи, грунтуються на різних принципах. 3 огляду на зміст (суть) пам'ятки неживої природи їх, можна розділити на три класи: геологічні, геоморфологічні та гідрологічні (Грищенко та ін., 1995).

Відповідно, геологічні пам'ятки доцільно розділити на п'ять типів:

1) стратиграфічні;

2) геохронологічні;

3) тектонічні;

4) палеонтологічні;

5) мінералого-петрографічні (Брусак і Бакун, 2011).

Геоморфологічні пам'ятки природи В. Брусак і В. Бакун класифікують за генезисом на окремі типи форм рельєфу (денудаційний, вулканічний, флювіальний тощо), а за морфологією - на види (скелі, печери, останці тощо) (Брусак і Бакун, 2011).

Гідрологічні пам'ятки $\quad$ В. Брусак $\mathrm{i} \quad$ В. Бакун поділяють на два типи: гідрогеологічні (виходи мінеральних вод, джерел, витоки річок) та поверхневогідрологічні (долини річок, озера тощо) (Брусак і Бакун, 2011).

У процесі збору геоморфологічної, геологічної та археологічної інформації використовувалися методи польових і камеральних досліджень, описовий метод, метод порівняльної оцінки та інші. Також використовувались дані літологічних, палеомалакологічних i археологічних досліджень. Зібраний та узагальнений фактичний матеріал дав змогу встановити цінність відслонень гірських порід, 
А. Яцишин, Р. Дмитрук, А. Гавінський Природопізнавальні та геоархеологічні маршрути... ISSN 2519-2620. Проблеми геоморфології і палеогеографії..2021. Вип. 1 (12), 155-178

виходів на денну поверхню підземних вод, археологічних стоянок як пам'яток неживої природи та охопити їх пропонованим новим маршрутом.

Результати. Георізноманіття східної частини міста Львова і його найближчих околиць дає змогу продовжити маршрут, який наразі закінчується на Чатових скелях, до південної частини Винниківського лісопарку, розташованого між Винниками на сході, Бережанами на півдні та Львовом (райони Пирогівка i Майорівка) - на заході і північному заході (рис. 2).

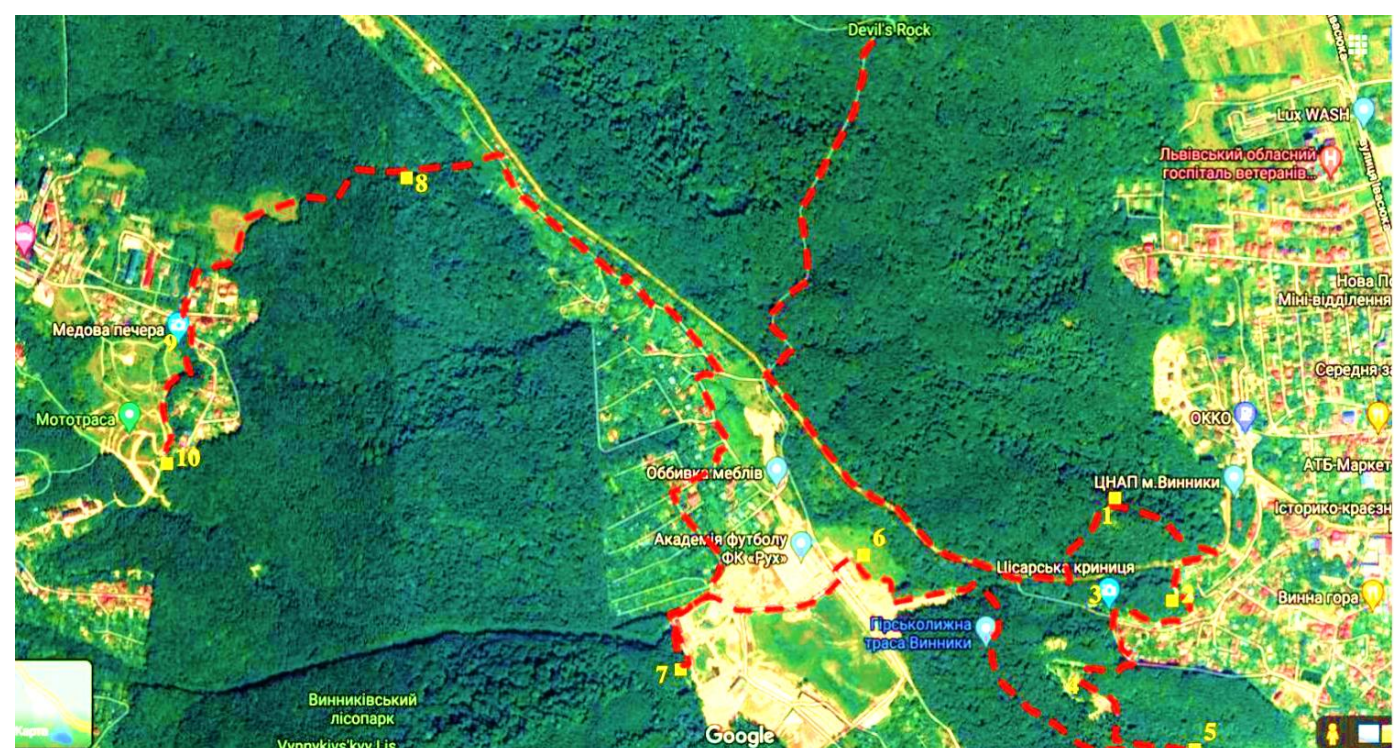

Рис. 2. Схема пропонованого природопізнавального та геоархеологічного маршруту "Чатові скелі - Винниківське озеро - Медова печера".

Цифрами позначені геоосвітні і природопізнавальні об’єкти: 1 - археологічна стоянка “Жупан”, 2 - археологічна стоянка "Шипшина", 3 - Цісарська криниця, 4 -

Пісковня, 5 - археологічна стоянка "Лисівка", 6 - археологічна стоянка

“Млинівці II”, 7 - археологічна стоянка “Млинівці I”, 8 - травертин, 9 - Медова печера, 10 - Джерело

Fig. 2. "Chatovi Rocks - Vynnykivske Lake - Medova Pechera" proposed geoeducational and nature-learning route diagram. Numbers indicate geo-educational and nature-learning objects: 1 - Zhupan archeological site, 2 - Shypshyna archeological site, 3

- Tsisarska Krynytsia, 4 - Piskovnia, 5 - Lysivka archeological site, 6 - "Mlynivtsi II" archeological site, 7 - "Mlynivtsi I" archeological site, 8 - travertine, 9 - Medova Pechera, $10-$ Well

Пропоноване продовження маршруту "Високий Замок (Піщана гора) Чатові скелі” до Цісарської криниці, Винниківського озера, а звідти до Медової печери забезпечить реалізацію геоосвітніх та рекреаційних запитів відвідувачів, що визначається мальовничістю рельєфу та складністю 
геоморфологічної і геологічної будови території. Мальовничість рельєфу зумовлена розташуванням досліджуваної території на стику двох геоморфологічних районів Поділля: Львівського плато і Пасмового Побужжя (Цись, 1962). Межа між ними представлена крутим схилом, який від Чатових скель прямує на південний схід від Винник. Перевищення Чатових скель над днищем долини Полтви, яка вже $\epsilon$ складовим елементом Пасмового Побужжя, сягає 140-150 м, а пересічна висота цього схилу коливається в межах 80-100 м.

У межах Львівського плато виокремлюють декілька підрайонів: власне Львівське плато, розчленовану північну частину плато, Львівсько-Бібрське горбогір'я, останцеві височини Цитадель, Чатову та Лисогірську (Цись, 1962). 3 перелічених вище шести підрайонів тільки два - розчленована північна частина Львівського плато i Чатова останцева височина - охоплені пропонованим нами новим маршрутом. Максимальні абсолютні відмітки припадають на Чатові скелі, де сягають 414 м, а поза вершиною коливаються в межах 350-370 м.

Пасмове Побужжя представлене поєднанням витягнутих з заходу на схід лесових підвищень, розділених широкими, коритоподібними, часто заболоченими долинами, які дренують річки Полтва, Марунька і дрібніші. Висота пасом над днищами долин, які їх розділяють, коливаються від 40-50 до 80-100 м зі зростанням відміток на захід. У межах території досліджень розташовані тільки два пасма: Винниківське і Чишківське. Абсолютні відмітки в межах пасом коливаються в діапазоні 275-290 м, а в днищі долини Полтви знижуються до 260-275 м.

У крутому схилі, яким Львівське плато відокремлене від Пасмового Побужжя, а також у бортах долин річок басейну Західного Бугу, які врізаються у Львівське плато, відслонюється широкий комплекс різновікових (крейдових, неогенових i четвертинних) та відмінних за походженням осадових нагромаджень.

Дочетвертинні відклади представлені нагромадженнями верхньої крейди i неогену (табл. 1).

Нагромадження четвертинного віку, які в межах плато і лесових пасом практично суцільним плащем покривають давніші утворення, об'єднані у такі вікові підрозділи (табл. 2): середньо-, верхньоплейстоценові та сучасні (Волошин, 1989; Волошин, 2009).

Четвертинні відклади сильно змиті на крутому схилі, який відокремлює Львівське плато і Пасмове Побужжя, а також у крутих бортах балок, річкових долин басейну Західного Бугу.

Довжина маршруту "Чатові скелі - Винниківське озеро - Медова печера" перевищує 9 км. Вздовж маршруту відвідувачі мають змогу ознайомитись 3 відслоненнями гірських порід, виходами на денну поверхню підземних вод (джерелами), багатими археологічними стоянками, які сукупно забезпечать природопізнавальну, геоархеологічну та рекреаційну функції.

Маршрут розпочинається на схилах Чатових скель, де для вивчення доступні нагромадження середнього баденію, які складені пісковиками (ратинські верстви), верхнього баденію, які розпочинаються товщею кайзервальдських верств, складених пісками і слабозцементованими пісковиками, і тернопільських верств, складених 
А. Яцишин, Р. Дмитрук, А. Гавінський Природопізнавальні та геоархеологічні маршрути... ISSN 2519-2620. Проблеми геоморфології і палеогеографії...2021. Вип. 1 (12), 155-178

Таблиця 1. Зведена стратиграфічна колонка дочетвертинних відкладів Львова (Волошин, 2009)

Table 1. Consolidated stratigraphic column of pre-Quaternary deposits of Lviv (Voloshyn, 2009)

\begin{tabular}{|c|c|c|c|c|c|}
\hline 产 & 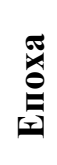 & $\stackrel{\circlearrowright}{\tilde{\alpha}}$ & 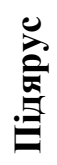 & 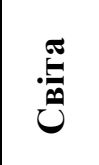 & Назва шарів і характеристика порід \\
\hline \multirow{4}{*}{ 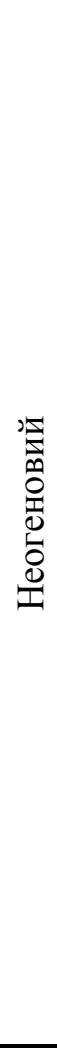 } & \multirow{4}{*}{ 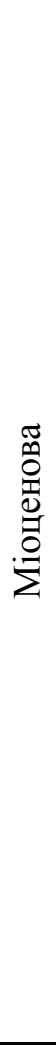 } & 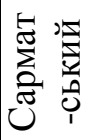 & 焉 & & $\begin{array}{l}\text { Волинські шари (глини, вапняки, мергелі, } \\
\text { пісковики, туфи) }\end{array}$ \\
\hline & & \multirow{3}{*}{ 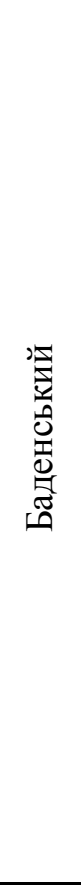 } & 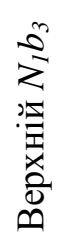 & 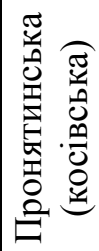 & $\begin{array}{l}\text { Тернопільські шари (глини, вапняки літотамнієві). } \\
\text { Прутські шари (глини, мергелі, піски, пісковики) } \\
\text { Вербовецькі шари (глини, пісковики, туфи) } \\
\text { Кайзервальдські (підгірські) шари (дрібнозернисті } \\
\text { піски, пісковики) }\end{array}$ \\
\hline & & & 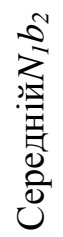 & 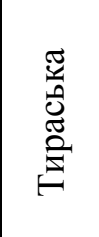 & $\begin{array}{l}\text { Ратинські шари (вапняки хемогенні, піски, } \\
\text { пісковики) } \\
\text { Тираські шари (гіпси, ангідрити) }\end{array}$ \\
\hline & & & 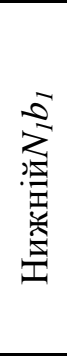 & 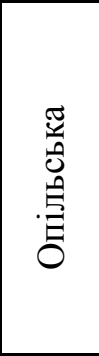 & 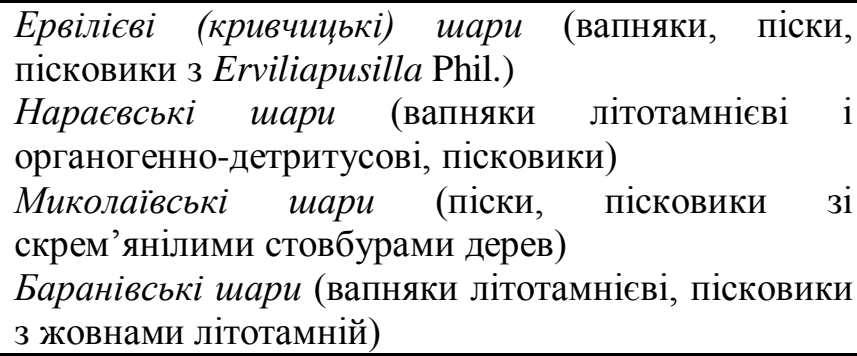 \\
\hline 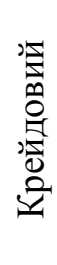 & 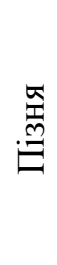 & 离 & 吝 & 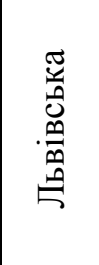 & Світло-сірі та голубувато-сірі мергелі \\
\hline
\end{tabular}


А. Яцишин, Р. Дмитрук, А. Гавінський Природопізнавальні та геоархеологічні маршрути...

ISSN 2519-2620. Проблеми геоморфології і палеогеографії...2021. Вип. 1 (12), 155-178

Таблиця 2. Зведена стратиграфічна колонка четвертинних відкладів Львова (Волошин, 2009)

Table 2. Consolidated stratigraphic column of Quaternary deposits of Lviv (Voloshyn, 2009)

\begin{tabular}{|c|c|c|c|}
\hline 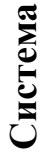 & \multicolumn{2}{|c|}{ 量 } & Генетичні типи і характеристика порід \\
\hline \multirow{3}{*}{ 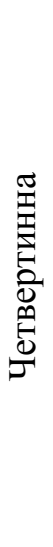 } & \multicolumn{2}{|c|}{ 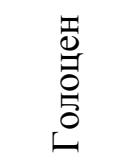 } & $\begin{array}{l}\text { Алювіальні, алювіально-болотні, болотні, елювіально- } \\
\text { делювіальні, пролювіальні. Суглинки, супіски, піски, торфи, } \\
\text { заторфовані суглинки і супіски, суглинки і супіски } 3 \\
\text { уламками осадових порід }\end{array}$ \\
\hline & \multirow{2}{*}{ 兽 } & ص్ & $\begin{array}{l}\text { Еолово-делювіальні, } \quad \text { алювіальні. } \\
\text { нагромадження (лесові, } \quad \text { Палеогрунтові, } \\
\text { горизонти), суглинки, супіски, піски }\end{array}$ \\
\hline & & 岂 & $\begin{array}{l}\text { Еолово-делювіальні, еолові. Леси, піски, піщано-глинисті } \\
\text { нагромадження з уламковим матеріалом }\end{array}$ \\
\hline
\end{tabular}

щільними піскуватими вапняками. На розмитій поверхні відкладів верхнього баденію залягають нагромадження волинських верств нижнього сармату, які складені пісковиками. Вони є наймолодшими неогеоновими утвореннями околиць Львова.

Розріз товщі нагромаджень, розкритих на схилах Чатових скель, ілюструє характер перебігу процесів осадонагромадження у морському басейні. Їхнє вивчення цінне 3 точки зору вирішення питань палеогеографії, літології, седиментології, палеоекології та інших природничих дисциплін (Яцишин і Дмитрук, 2020). Розріз може виконувати наукову (об'єкт вивчення процесів осадонагромадження у відкритому морі, палеонтології, літології та інших природничих дисциплін), навчальну, освітню, пізнавальну (об’єкт навчальних екскурсій учнів шкіл, польових занять для студентів географічного, геологічного факультетів), екологічну (об'єкт екологічних стежин та екологічного виховання) функції.

Чатові скелі добре доступні для вивчення. Вони піддаються антропогенному впливові, оскільки скелі активно використовують для занять 3 альпінізму. Серед природних явищ, які інтенсивно розвиваються на схилах скель, можна назвати обвально-осипні та інші денудаційні процеси: вони дещо змінюють вигляд Чатових скель, однак не становлять для них великої загрози. Проте існує потреба в благоустрої території: встановленні інформаційних стендів, збільшенні кількості смітникових урн, встановленні кількох біотуалетів у доступних місцях тощо. 
А. Яцишин, Р. Дмитрук, А. Гавінський Природопізнавальні та геоархеологічні маршрути... ISSN 2519-2620. Проблеми геоморфології і палеогеографії...2021. Вип. 1 (12), 155-178

Далі маршрут спускається до вулиці Личаківської і вздовж неї трасується в напрямі м. Винники, на західній околиці яких локалізована серія археологічних стоянок: Жупан, Шипшина, Лисівка, а також Цісарська криниця. Поруч із криницею і стоянкою Лисівка розташований цінний природопізнавальний об'єкт - Пісковня це закладений наприкінці XIX ст. кар'єр з видобутку сировини для склозаводів та будівельних матеріалів (піску, пісковиків і вапняків).

Цісарська криниця у Винниках своєю історією та легендами приваблює відвідувачів. Криничка збудована 1826 р. для потреб місцевої тютюнової фабрики. Важливо, що тепер вона належить до комплексу природно-антропогенного об'єкта екологічного та релігійного туризму екскурсійної спрямованості “Стежка Митрополита Андрея Шептицького" на горі Шипшина, відкритого 20 листопада 2020 р. “Стежка" збудована на честь Митрополита, який у 1930-х роках полюбляв тут відпочивати. 3 оглядового майданчика відкривається мальовничий краєвид на долину Маруньки та навколишні села. Об'єкт довжиною у 500 м викладений бруківкою з відповідною інфраструктурою та трьома зупинками з монументальними скульптурами. Поруч із Цісарською криницею встановлено бювет для потреби подорожуючих (Білоус, Гавінський і Оприск, 2016).

Зазначений комплекс доповнений археологічними поселеннями, розташованими на горі Шипшина (рис. 3). Сама гора $є$ невеликою, оскільки ще за австрійських часів зі східного боку частково зруйнована кар'єром з видобування вапняку. Вивчення цієї багатошарової пам'ятки припало на 1994, 2014 та 2015 роки. Зазначимо, що свого часу митрополит Андрей Шептицький активно сприяв розвиткові археології в Галичині. Випадково чи ні, проте історія повторюється: завдяки митрополитові виконано подальші дослідження. Головним було поселення черепино-лагодівської групи ранньозалізного часу. Від нього залишилися глибокі господарські ями, заглиблені житлові споруди та значна кількість побутових речей, здебільшого фрагменти кераміки.

Серед посуду вирізняються банкоподібні горщики з наскрізними проколами під вінцями, черпаки, миски конічної форми. Вироби часто прикрашали пружками 3 пальцевими заглибленнями, защипами та нігтевими вдавленнями. Окремими екземплярами представлені накривки до горщиків (Бандрівський, 2003; Гавінський, Білас і Гринчишин, 2015; Гавінський, Бандрівський і Оприск, 2016). Меншою мірою представлені матеріали інших археологічних культур, які, очевидно, перебували тут тимчасово. До культури лійчастого посуду належить фрагмент ручки черпака типу "ansalunata $\square$, а до тщінецької культури доби бронзи (кінець III тис. до н. е.) - уламок посудини зі шнуровим орнаментом.

Праворуч від г. Шипшина знаходиться г. Лисівка на якій, завдяки прадавньому лісу, чудово збереглося поселення культури лійчастого посуду. Це одне з небагатьох укріплених енеолітичних селищ на території України зі вцілілим валом і ровом. Багаторічні дослідження, які продовжують останніми роками, увінчались важливими і цікавими результатами (Пелещишин, 1994; Rybickaiin., 2017; Гавінський, Білас i Рибіцька, 2020; Гавінський, Білас і Рибіцька, 2020а). Центральна частина поселення не густо забудована житловими спорудами. Вони мали наземну стовпову 

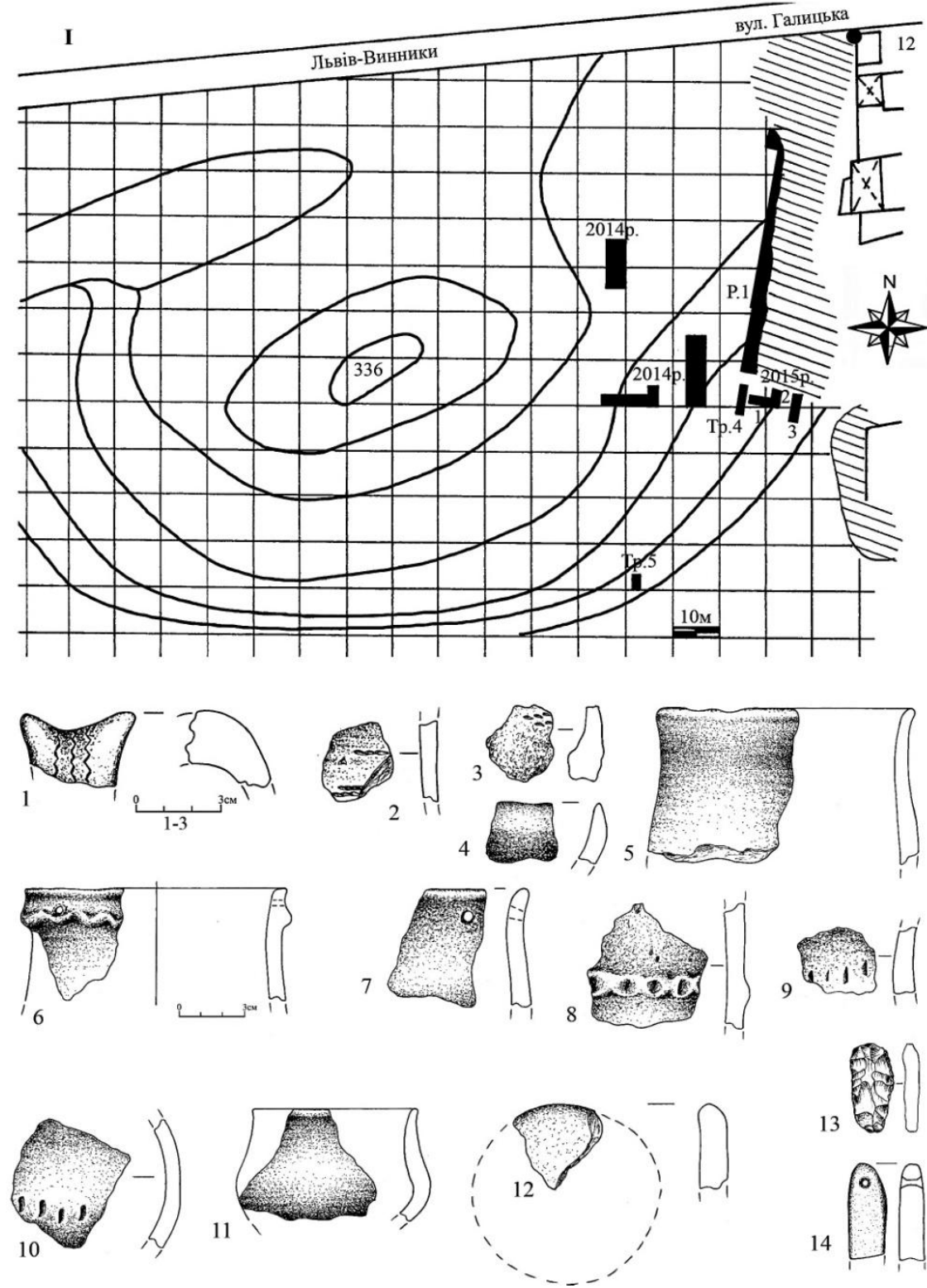

13

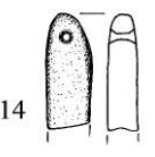

Рис. 3. Археологічні поселення на горі Шипшина. Умовні позначення: I - план розкопів за 2014-2015 рр.; 1-13 - знахідки кераміки, кременю та каменю Fig. 3. Archaeological settlementon Shypshyna Mount. Legend: I - excavation plan for 2014-2015; 1-13 - finds of ceramics, flint and stone

конструкцію прямокутної форми площею близько $20 \mathrm{~m}^{2}$, стіни, переплетені пруттям, яке згодом обмазували глиною. 3 певних причин деякі хати спалені, від чого 
А. Яцишин, Р. Дмитрук, А. Гавінський Природопізнавальні та геоархеологічні маршрути...

ISSN 2519-2620. Проблеми геоморфології і палеогеографії...2021. Вип. 1 (12), 155-178

залишилися завали перепаленої глини-обмазки. Господарські ями розташовані по північному краю гори. Це своєрідні пивниці, окремі 3 яких мали підбої грушоподібної в перерізі форми. 3 часом їхні стінки почали осипатися, отож їх використовували для складування сміття. На відміну від житла, де обмаль предметів, у цих ямах виявилась величезна кількість матеріалу: здебільшого уламки посуду, розбиті горщики, які згодом вдалося реконструювати, пошкоджені та цілі знаряддя праці, предмети прядіння і ткацтва, символічні, а іноді й мідні предмети (рис. 4).
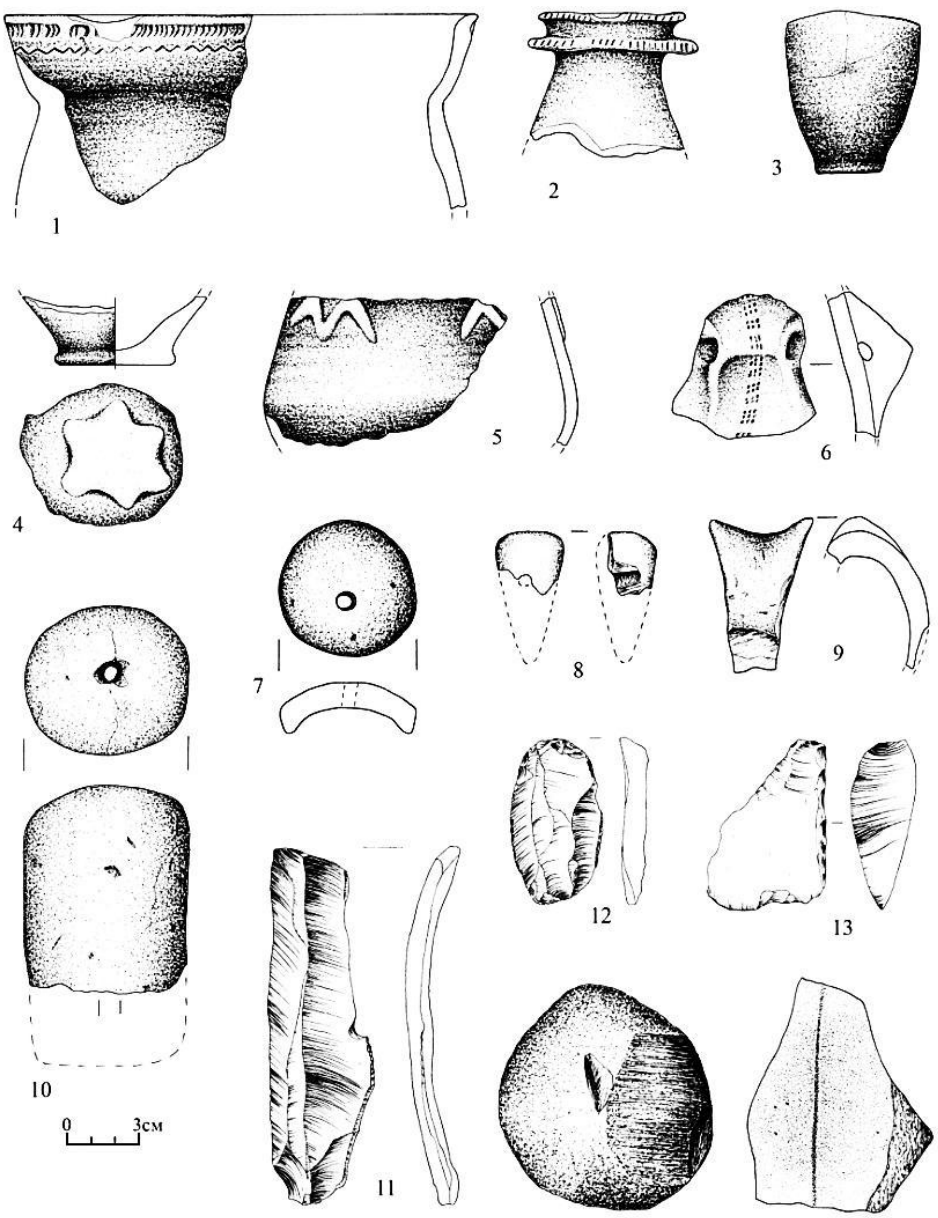

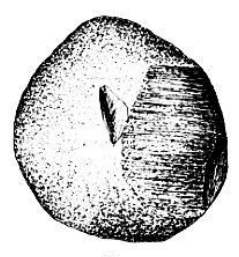

14

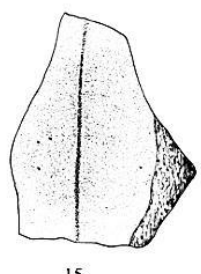

Рис. 4. Артефакти з поселення Лисівка. Вироби культури лійчастого посуду

Fig. 4. Artifacts from Lysivka settlement. Products of funnel ware culture

Виявлений посуд відзначається стрункими формами, залощеною до блиску поверхнею та багатим орнаментом. Вирізняються особливі форми, притаманні лише 
цій культурі: фляги на декорованих ніжках; черпаки 3 крильцеподібними ручками; горщики прикрашені пластичними літерами "М”. До рідкісних предметів належить уламок глиняної модельки сокири культового призначення. Зазначимо, що на поселенні знайдено чималу кількість трипільського посуду, що засвідчує тісні взаємозв'язки зі східними сусідами. Доволі важливим моментом цих контактів $\epsilon$ певний відсоток кераміки культури лійчастого посуду з наслідуванням технології трипільської культури (зокрема, й фарбуванням поверхні), що засвідчує певний синкретичний характер цих стосунків. Виконані лабораторні дослідження дали змогу окреслити час існування цього поселення в межах 3500-3300 pp. до н. е.

Окремими матеріалами на горі Лисівка представлені й інші культури. Тут, зокрема, виявлено пізньопалеолітичні патиновані знаряддя, серед яких вирізняється виріб із шоколадного кременю, поклади якого фіксують за кілька сотень кілометрів на захід, що засвідчує його привізний характер. Тимчасово тут перебували представники волино-люблінської та межановицької культури доби бронзи.

Цікава пам'ятка знаходиться праворуч і від г. Шипшина - на високій горі Жупан (391,3 м н. р. м.). Окрім поселення культури лійчастого посуду, тут розкопали пізньотрипільське селище, що становить крайній західний пункт цієї культури i знаходиться в середовищі лійчастих кубків (рис. 5). Свого часу М. Пелещишин писав про одночасове спільне проживання двох общин на цій горі (Пелещишин, 1998). Останні дослідження довели, що ці поселення були різночасовими з різницею приблизно у 200 років, а порушений культурний шар не дає змоги стратиграфічно розділити артефакти (Diachenko et al., 2019; Вертелецький та ін, 2020). Водночас можна стверджувати про глибину контактів обох культур та шляхи пересування населення пізнього трипілля, що належить до так званої гордінештської групи, територія поширення якої сягає сучасних Молдови, Румунії, Середнього Дністра та Волині.

Поруч 3 Цісарською криницею і стоянкою “Лисівка" розташований цінний природопізнавальний і рекреаційний об'єкт - “Пісковня” (рис. 6). Йдеться про закинутий у другій половині минулого століття кар'єр з видобутку кварцових пісків. Їх використовували для будівництва, а також потреб скляної промисловості, яка активно розвивалась того часу у Львові. Кар'єр функціонував 3 кінця ХІХ до середини XX-го століття. Основними чинниками, які зумовили поступовий занепад кар'єру, були виробіток високоякісних пісків (у товщі, яку розробляли, спостерігається багато включень вапняків та слабкозцементованих пісковиків), а також знищення залізниці, яка проходила повз кар'єр, та поступове закриття склозаводів. Сьогодні на місці закинутого кар'єру залишилось пониження, оточене 3 усіх сторін різної висоти стінками, в яких відслонюються товщі неогенових (верхньобаденських) утворень. Іноді висота стінок перевищує 20 м. У них відслонюються горизонтально залягаючі товщі пісків 3 прошарками пісковиків та вапняків. Потужність прошарків є змінною - від кількох сантиметрів до 0,3-0,4 м. Загальний колір товщі - жовтувато-білий, що зумовлено складом (білі кварцові піски та світло-жовті вапняки). Сьогодні територію кар'єру використовує спортивно-тренувальний майданчик ГО “Винниківський клуб мотоциклетного 
А. Яцишин, Р. Дмитрук, А. Гавінський Природопізнавальні та геоархеологічні маршрути... ISSN 2519-2620. Проблеми геоморфології і палеогеографії...2021. Вип. 1 (12), 155-178

спорту “Драйв”, хоча місцевими активістами порушено питання щодо заборони проведення таких заходів у всій Винниківській лісопарковій зоні 3 метою запобігання нищенню природи (передусім рослинного і грунтового покривів).
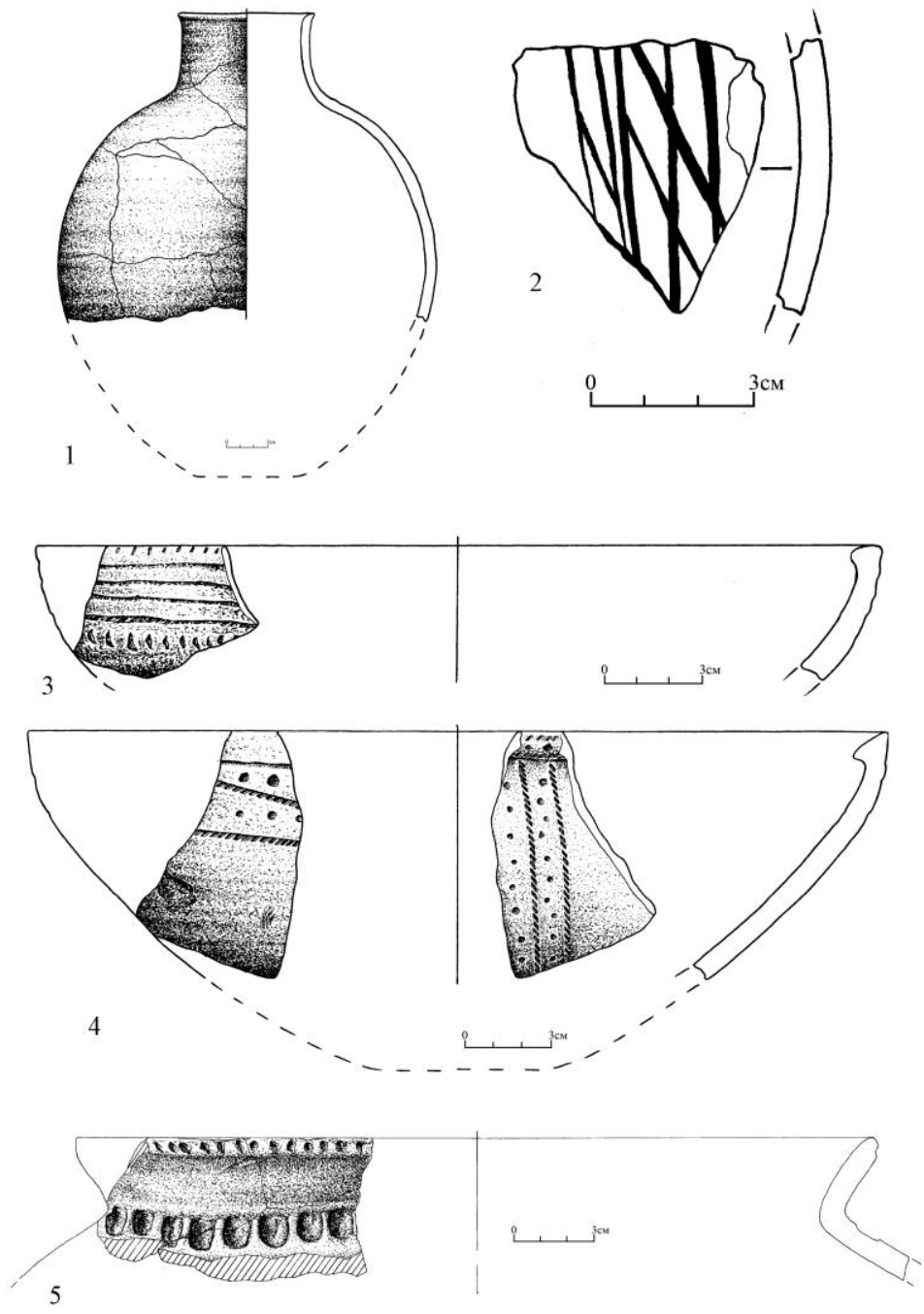

Рис. 5. Артефакти з поселення Жупан. Посуд трипільської культури

Fig. 5. Artifacts from Zhupan settlement. Utensils of Trypillia culture

Західніше, у бортах долини р. Маруньки, поблизу тепер активно реконструйованого Винниківського озера, опрацьована серія геоархеологічних пам'яток “Млинівці I” і “Млинівці II”. У зв'язку з будівництвом нового спортивнооздоровчого комплексу постала необхідність рятівних досліджень стоянок. Наукові співробітники Історико-краєзнавчого музею м. Винники розкопували два поселення 
- “Млинівці I" і “Млинівці II”, які, відповідно, знаходились на правому і лівому борті долини річки.

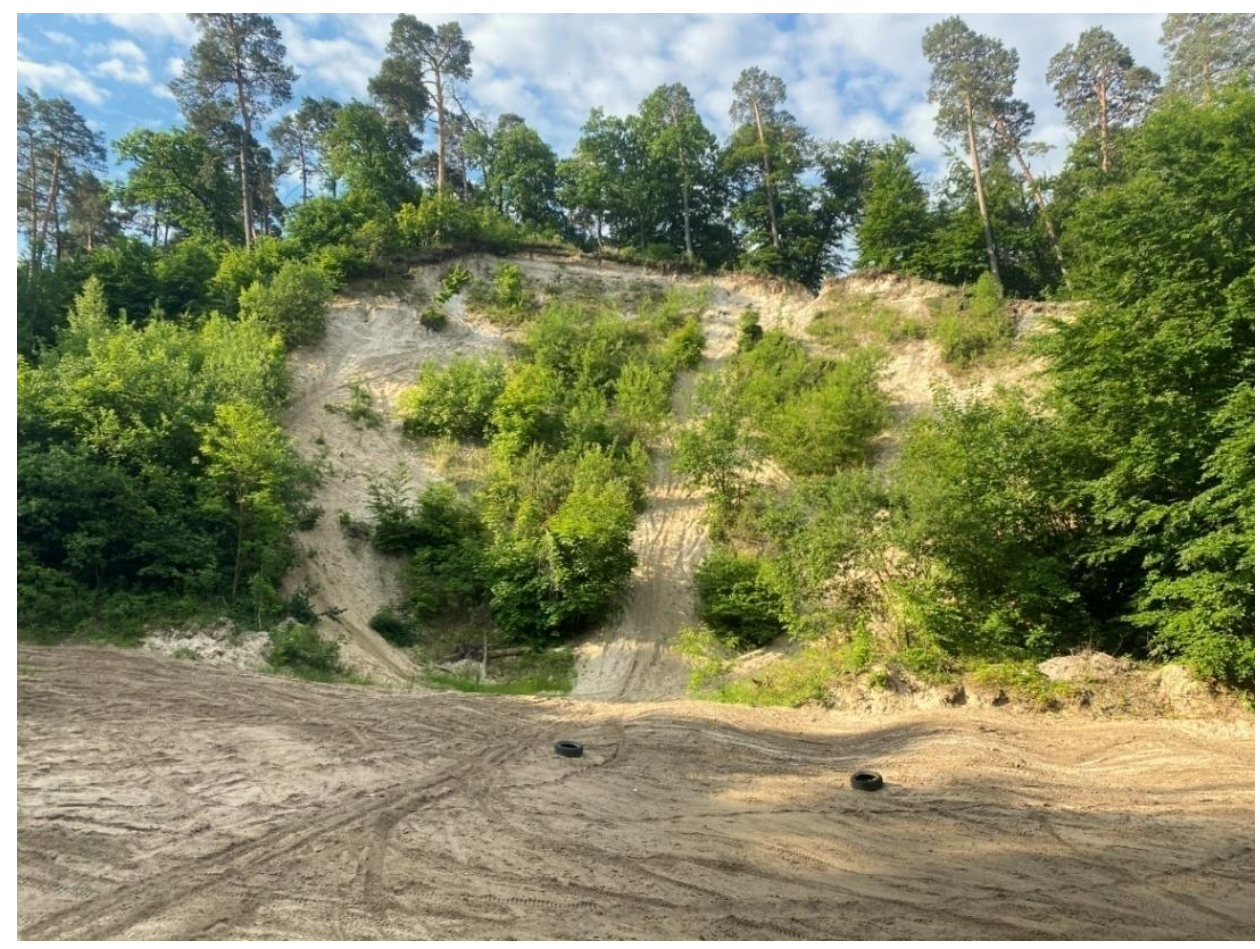

Рис. 6. Кар'єр “Пісковня”

Fig. 6. Piskovnia quarry

На пункті “Млинівці I” зафіксовано рештки житлового приміщення зі слідами вогнища у вигляді скупчення глиняної обмазки та одну господарську яму. Можливо, ці об'єкти залишені носіями енеолітичної культури лійчастого посуду другої половини IV ст. до н. е.

Значна кількість археологічних культур представлена на пам'ятці “Млинівці II”. На площі у 170 м² виявлено десять різночасових об'єктів. Найбільш ранній горизонт представлений волино-люблінською культурою першої половини IV тис. до н. е., від неї залишилась котловина якоїсь споруди чотирикутної форми 3 двома ямами у кутах і вогнищем на долівці. Майже однакових сім господарських ям діаметрами 1,2-1,6 м зараховано до черепино-лагодівської групи ранньозалізного часу VIIVI ст. до н. е. Про раннє заселення околиць Львова та Винник свідчить заглиблене житло із піччю-кам'янкою IX-X ст., згодом на цьому ж місці існувало селище княжого періоду, датоване XII ст.(Гринчишин та ін., 2019).

Артефакти, здобуті під час археологічних досліджень стоянок, розкритих на західній околиці м. Винники, можна оглянути у сучасній інноваційній експозиції 
Історико-краєзнавчого музею м. Винники та Археологічного музею Львівського університету ім. І. Франка.

Ще одним з пропонованих об'єктів, який доцільно долучити до розроблюваного маршруту, є закинутий кар'єр поблизу хутора Волиця, що на південь від Винник. Тут у другій половині ХХ-го століття видобували леси для виробництва цегли. Припинили його розробляти у 80 -х роках минулого століття. Розріз розташований на стику північного уступу Поділля 3 найпівденнішим 3 шести лесових пасом Пасмового Побужжя - Дмитровицьким (Чишківським). Розріз є типовим для Пасмового Побужжя i розкриває будову майже 10-метрової товщі верхньоплейстоценових лесів. Зазначимо, що нижня, найдавніша частина відслонення, що знаходиться у виїмці, важкодоступна для вивчення, оскільки “заплила” більш молодими лесами. Надзвичайно цікавою є північна стінка кар'єру, яка розташована найближче до будинків. Тут відслонюється складно пликативно деформована пачка (рис. 7).

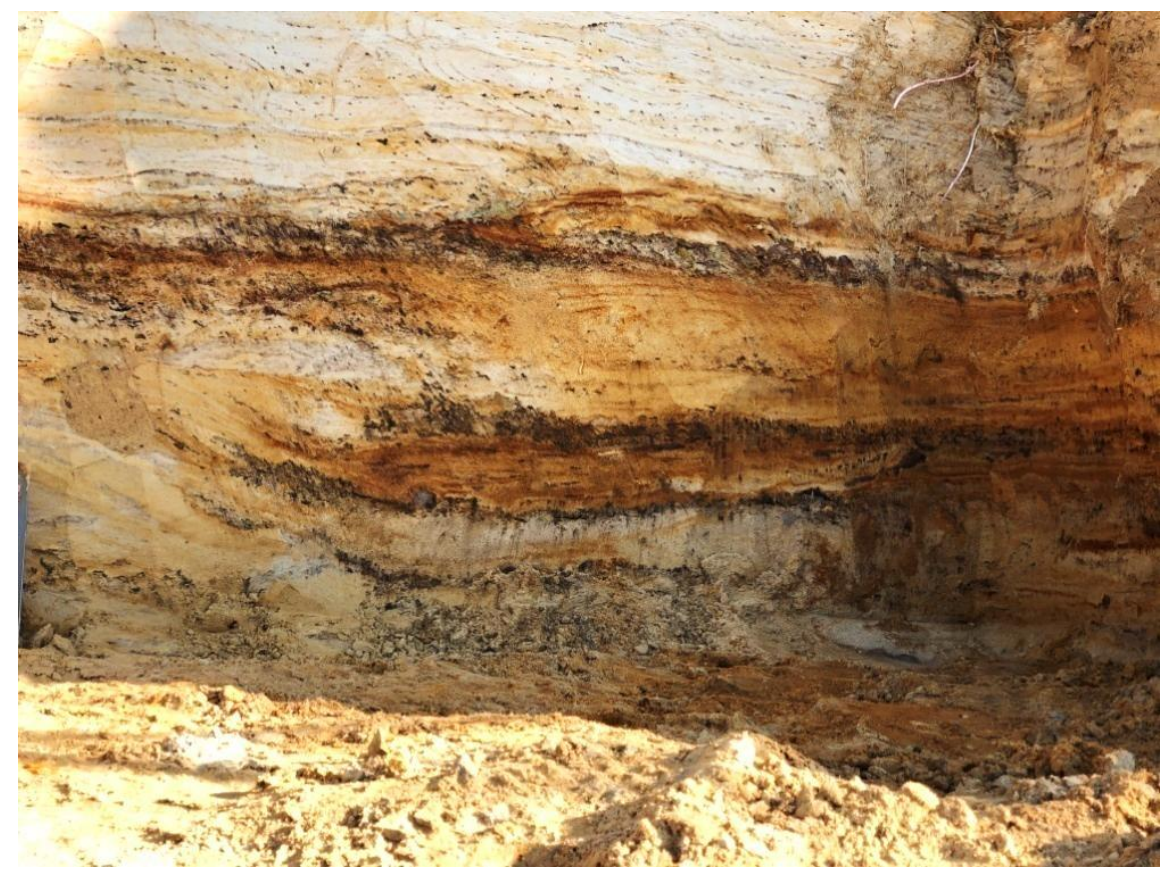

Рис. 7. Пликативно деформована пачка лесів розрізу Волиця

Fig. 7. Plicatively deformed bundle of the Volytsia section forests

Природа цих деформацій - розвиток схилових (делювіально-соліфлюкційних) процесів на слабозадернованих схилах у холодні відрізки плейстоцену. Вся товща має палевий колір, шаруватість підкреслюється смугами бурого та чорного озалізнення, іноді - й ортзандами. 
Ще одним цікавим елементом цього розрізу $\epsilon$ наймолодші леси. Вони переповнені численними мушлями молюсків. Найтиповішими серед виявлених $є$ види Pupilla muscorum, Pupilla loessica, Vallonia tenuilabris, Trichia hispida, Succinea oblonga, що вказують на тогочасні холодні (субарктичні) умови.

Упродовж тривалого часу важливим центром відпочинку в західній околиці Винник було Винниківське озеро. Проте 3 кінця 2018 року цю територію використовує Академія футболу ФК “Рух”, отож сьогодні вона вилучена з переліку об’єктів рекреаційного фонду Львівської ОТГ. Зазначимо, що тут в перспективі організовуватимуть відпочинкову зону, головними об'єктами якої будуть відновлене озеро та гірськолижний витяг. Це сприятиме збільшенню кількості відвідувачів зазначеної території i, як наслідок, зростання інтересу до пропонованого пішого маршруту.

Від археологічних пам'яток “Млинівці I" i “Млинівці II” траса маршруту скеровується через Винниківський лісопарк у бік Медової печери.

У долині однієї з правих приток р. Маруньки, на віддалі близько 2 км на північний захід від Цісарської криниці, виявлений доволі великий травертин каскад невеличких (зазвичай висотою не більше 10-15 см) терас у руслі потоку (рис. 8).

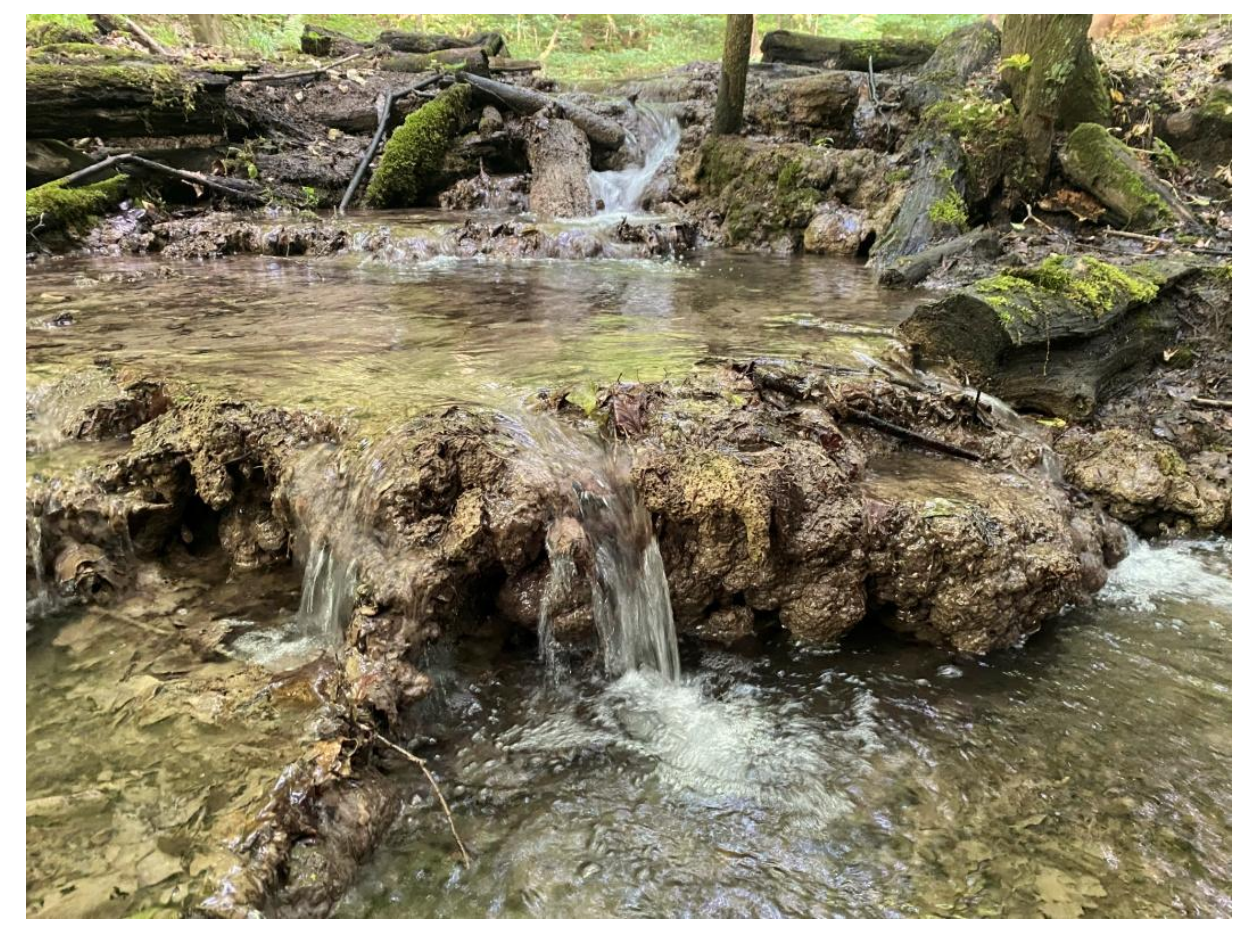

Рис. 8. Травертин в долині притоки р. Маруньки

Fig. 8. Travertine in the valley of the Marunka River tributary 
А. Яцишин, Р. Дмитрук, А. Гавінський Природопізнавальні та геоархеологічні маршрути... ISSN 2519-2620. Проблеми геоморфології і палеогеографії...2021. Вип. 1 (12), 155-178

Загальна протяжність травертинового тіла складає щонайменше 20 м за сумарної висоти понад один метр. Вперше цю знахідку описали 2020 року біологи О. Орлов на М. Рагуліна як місце розповсюдження кальцефільних видів рослин (У Львові знайшли..., 2020). Тіло травертину складене доволі пористими вапняками, зазвичай темно-сірого кольору. Його текстурні особливості вказують та фітогенну природу травертину: наявна рослинність сприяє випаданню в цьому місці карбонату кальцію $\left(\mathrm{CaCO}_{3}\right)$ в осад (Alexandrowicz, 2004). Також наголосимо, що зазначений процес не припиняється і сьогодні. Травертин розташований у доступному місці - власне тут потік пересікає закинута лісова дорога, що сприяє залученню його до пропонованого маршруту.

Медова печера (рис. 9) розташована на віддалі менше одного кілометра на південний захід від травертину. Власне печера антропогенного походження, виникла під час добування вапняків для будівельних потреб. Вапняки відслонюються у лівому (північному) борті великої балки, яка впадає у долину р. Марунька. Вапняки хемогенні, світло- і жовтувато-сірі, щільні, кавернозні, репрезентують нагромадження середньобаденських ратинських шарів (їхнім стратиграфічним відповідником $є$ пісковики, які відслонюються на схилах Чатових скель).

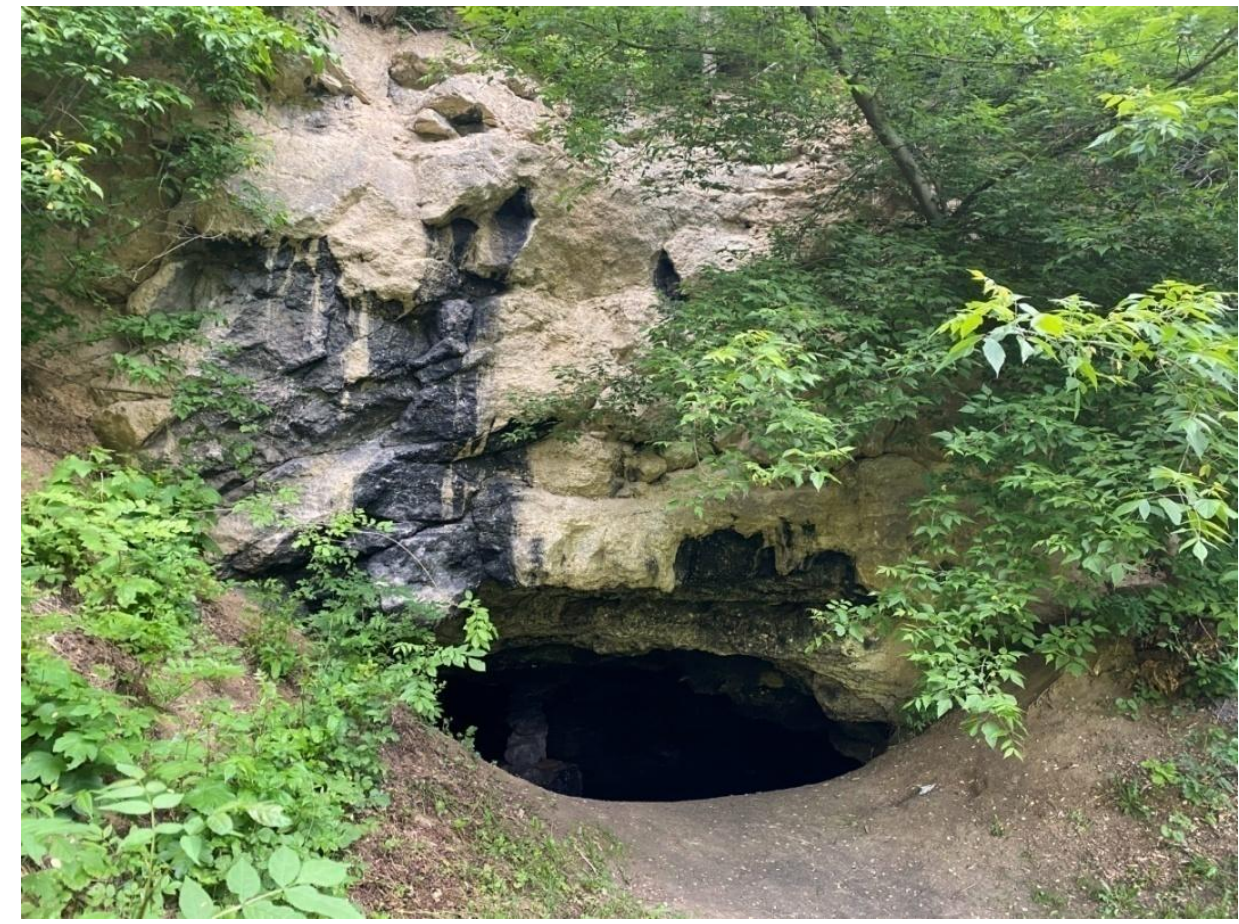

Рис. 9. Медова печера (відслонення ратинських хемогенних вапняків)

Fig. 9. Medova Pechera (exposure of Ratyno hemogenic limestones) 
А. Яцишин, Р. Дмитрук, А. Гавінський Природопізнавальні та геоархеологічні маршрути...

Вивчення відслонення ратинських хемогенних вапняків цінне 3 точки зору вирішення питань палеогеографії, літології, седиментології, палеоекології та ін. Розріз може виконувати наукову (об'єкт вивчення процесів осадонагромадження у відкритому морі, палеонтології, літології), навчальну, освітню, пізнавальну (об’єкт навчальних екскурсій учнів шкіл, польових занять для студентів географічного, геологічного факультетів), екологічну (об'єкт екологічних стежин та екологічного виховання) функції.

Медова печера добре доступна для вивчення. Антропогенний вплив на неї значний, отож існує потреба благоустрою території. Серед природних явищ, які інтенсивно розвиваються навколо скель, можна назвати обвально-осипні процеси, процеси лінійної ерозії та інші денудаційно-акумулятивні процеси.

На відстані близько 400 м на південь від відслонення вапняків у правому борті балки є джерело (рис. 10), яке фіксує контакт верхньокрейдових мергелів (глинистої кори вивітрювання мергелів), що формують водотрив, і водоносних неогенових нагромаджень, які перекривають товщу мергелів. Неогенові нагромадження представлені грубошаруватими літотамнієвими вапняками (баранівські верстви).

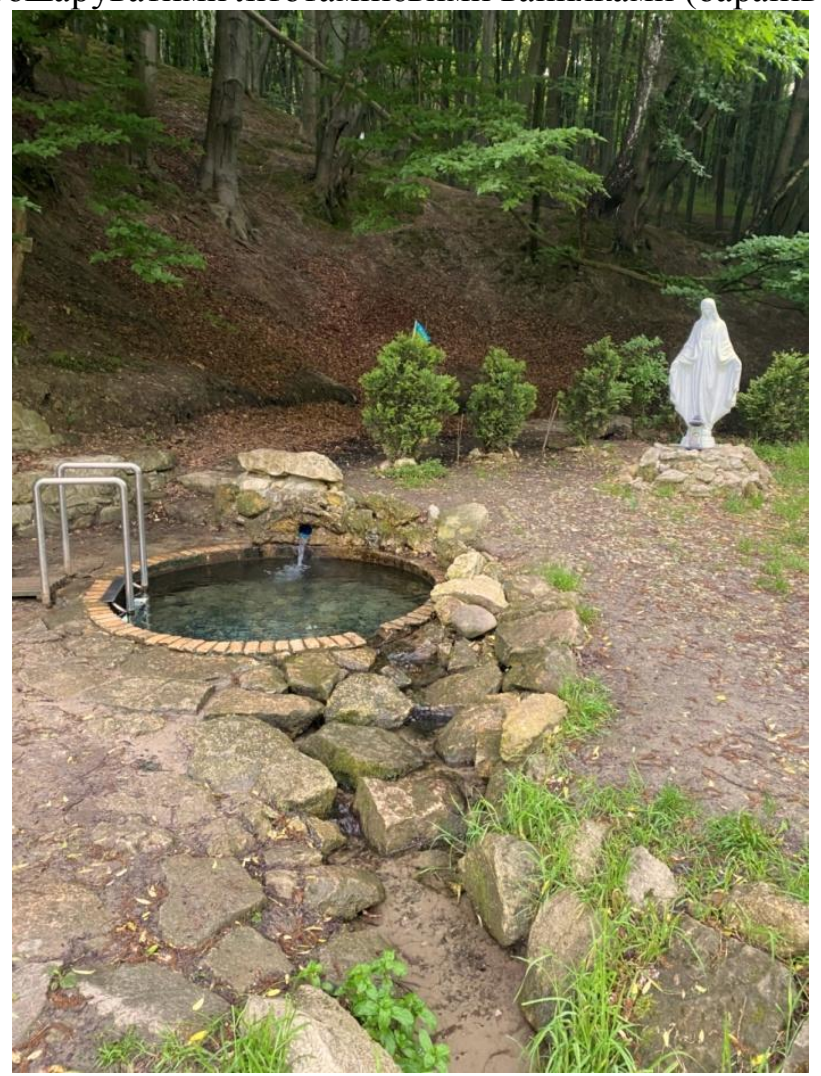

Рис. 10. Джерело у підніжжі Медової печери

Fig. 10. Well at the foot of the Medova Pechera 
А. Яцишин, Р. Дмитрук, А. Гавінський Природопізнавальні та геоархеологічні маршрути... ISSN 2519-2620. Проблеми геоморфології і палеогеографії...2021. Вип. 1 (12), 155-178

Вивчення виходу на денну поверхню підземних вод (джерела) цінне з точки зору виконання навчальної, освітньої, пізнавальної (об’єкт навчальних екскурсій учнів шкіл, польових занять для студентів географічного, геологічного факультетів), екологічну (об'єкт екологічних стежин та екологічного виховання) функцій. Джерело добре доступне для вивчення. Антропогенний вплив на нього значний, отож існує потреба в моніторингу стану джерела.

Завершується маршрут "Чатові скелі - Винниківське озеро - Медова печера" у надзвичайно мальовничому місці - неподалік від траси для мотоперегонів. Рекреаційну функцію здатні виконати не тільки перегляд мотоперегонів, а й мальовничий рельєф у межах мототраси і в іiї найближчих околицях.

Розроблений маршрут "Чатові скелі - Винниківське озеро - Медова печера" дає доступ до таких типів пам'яток природи:

1) стратиграфічних та геохронологічних (Чатові скелі, Медова печера, Пісковня, травертин, серія археологічних стоянок);

2) мінералого-петрографічних (Чатові скелі, Медова печера, Пісковня);

3) палеонтологічних (Чатові скелі, Пісковня, травертин);

4) геоморфологічних (Чатова останцева височина, Медова печера, Пісковня, долина р. Марунька і територія Винниківського лісопарку);

5) мальовничих (Чатова останцева височина, Медова печера, Пісковня, долина p. Марунька і територія Винниківського лісопарку).

Обговорення і висновки. Східній частині м. Львова притаманний надзвичайно високий природопізнавальний, екоосвітній та геоархеологічний потенціал, який, наразі, не використовують на повну потужність. Навіть такі об'єкти неживої природи, як Чатові скелі, Медова печера, які добре відомі прихильникам активного відпочинку та фахівцям-природничникам, передусім геологам, досі так і не набули широкої популярності серед мешканців Львова і його гостей. Хоча обидва об'єкти добре доступні та цінні з точки зору виконання екологічної (об'єкт екологічних стежин та екологічного виховання), навчальної, освітньої, пізнавальної (об'єкт навчальних екскурсій учнів шкіл, польових занять для студентів географічного, геологічного факультетів) функцій, не надто високу їхню популярність можна пов'язати, насамперед, 3 відсутністю належної інфраструктури - промаркованих стежок та інформаційних стендів.

Інші об’єкти, передусім археологічні пам'ятки, ще менше відомі мешканцям Львова. Однак вони надзвичайно цінні з точки зору ілюстрації історії заселення території м. Львова та його найближчих околиць і здатні виконувати навчальну, освітню, пізнавальну (об'єкт навчальних екскурсій учнів шкіл, польових занять для студентів географічного, історичного факультетів) функції. Деякі 3 них $\epsilon$ унікальними, зокрема - пам'ятка на горі Лисівка, адже це одне 3 небагатьох укріплених енеолітичних селищ на території України зі збереженим валом і ровом. Пам'ятка багата величезною кількістю матеріалу, здебільшого, уламків посуду, знарядь праці, предметів прядіння і ткацтва і інших. На поселенні також знайдено чималу кількість трипільського посуду, який свідчить про тісні взаємозв'язки із східними сусідами. Окремими матеріалами представлені й інші культури. Зокрема, 
тут виявлено пізньопалеолітичні патиновані знаряддя. Тимчасово тут перебували представники волино-люблінської та межановіцької культури доби бронзи.

На горі Жупан, окрім поселення культури лійчастого посуду, є пізньотрипільське селище. Це поселення дозволяє відтворити глибину взаємних контактів згадуваних культур та шляхи пересування населення пізнього трипілля.

На пам’ятках “Млинівці I" та “Млинівці II”, що розташовані по бортах p. Маруньки в районі Винниківського озера, виявлено десять різночасових об'єктів. Найдавніший горизонт представлений волино-люблінською культурою першої половини IV тис. до н. е, а наймолодший культурний горизонт фіксований селищем княжого періоду, датованого ХІІ ст. У зв'язку 3 будівництвом спортивнооздоровчого комплексу існує реальна загроза їх збереженню.

Спільною і головною проблемою збереження та популяризації серед мешканців Львова, Винник та інших населених пунктів археологічних пам'яток є відсутність промаркованих стежок та інформаційних стендів, хоча частину маршруту, яка сполучає стоянки Шипшина, Лисівка, Цісарську криницю і Пісковню, частково промарковано під час створення комплексу природно-антропогенного об'єкта екологічного та релігійного туризму екскурсійної спрямованості “Стежка Митрополита Андрея Шептицького”. Доступність цього скупчення об’єктів є навіть ліпшою, ніж Чатових скель.

Окрім реальної загрози збереження пам'яток “Млинівці I" і “Млинівці II”, яку створює, як уже зазначено вище, будівництво нового спортивно-оздоровчого комплексу, розгорнутого навколо Винниківського озера, в майбутньому комплекс також формуватиме нові перспективи використання мальовничого рельєфу, складної геоморфологічної та геологічної будови східної частини м. Львова у рекреаційних і природопізнавальних заходах. Безперечно, новий спортивно-оздоровчий комплекс сприятиме зростанню відвідуваності території Винниківського лісопарку, долини p. Марунька. Отож потреба в налагодженні відповідної інфраструктури вздовж маршруту "Чатові скелі - Винниківське озеро - Медова печера" очевидна вже сьогодні.

Подяка. Дослідження частково фінансоване Національним фондом досліджень України і $є$ частиною проекту “Розвиток палеокріогенних процесів у плейстоценовій лесово-грунтовій серії України: інженерно-геологічний, грунтовий, кліматичний, природоохоронний аспекти" (реєстраційний номер 2020.02/0165).

\section{СПИСОК ВИКОРИСТАНОЇ ЛІТЕРАТУРИ}

Бандрівський М. Поселення ранньозалізного віку у Винниках та проблеми завершального етапу існування висоцької культури / М. Бандрівський // Археологічні дослідження Львівського університету. - Львів. - 2003. - Вип. 6. C. 204-219.

Білоус Л. Стежка митрополита Андрея Шептицького у Винниках / Л. Білоус, А. Гавінський, В. Оприск // Лемківський календар на 2017 рік [Текст] : альманах. - Львів, 2016. - Ч. 66. - С. 154-159. 
А. Яцишин, Р. Дмитрук, А. Гавінський Природопізнавальні та геоархеологічні маршрути... ISSN 2519-2620. Проблеми геоморфології і палеогеографії...2021. Вип. 1 (12), 155-178

Брусак В. П. Географічні дослідження в заповідниках / В. П. Брусак, Ю. В. Зінько // Природничі дослідження на Розточчі : зб. наук.-техн. праць. - Львів, 1995. C. 5-14.

Брусак В. Методичні аспекти класифікації і паспортизації геолого-геоморфологічних пам'яток природи / В. Брусак, В. Бакун // Вісник Львівського університету. Серія географічна. - 2011. - Вип. 39. - С. 44-51.

Вертелецький Д. Розкопки на горі Жупан у м. Винники / Д. Вертелецький, Н. Білас, А. Гавінський, М. Рибіцька // Археологічні дослідження в Україні 2019 р.. - 2020. - C. 146-147.

Волошин П. Характеристика природных условий г. Львова / П. Волошин // Раздел к генплану города Львова. - Львов: Львов. ф-л УкрГИИНТИЗ, 1989. - Т. 1. - 120 с. Текст отчёта. (Фонди інституту УкрзахідДІІНТР).

Волошин П. Методичні рекомендації 3 геолого-геоморфологічного розділу загальноекологічної практики (для студентів другого курсу географічного факультету спеціальності "Екологія, охорона навколишнього середовища та збалансоване природокористування”) / П. Волошин. - Львів : Вид-во Львів. унту, 2009. -61 с.

Гавінський А. Розкопки у Винниках на горі Шипшина / А. Гавінський, Н. Білас, Б. Гринчишин // Археологічні дослідження в Україні 2013. - 2015. - С. 121-122.

Гавінський А. Рятівні розкопки у Винниках біля Львова / А. Гавінський, М. Бандрівський, В. Оприск // Археологічні дослідження в Україні 2015 р. - 2016. - С. 92-93.

Гавінський А. Розкопки поселення культури лійчастого посуду Винники-Лисівка у 2017-2018 pp. / А. Гавінський, Н. Білас, М. Рибіцька // Археологічні дослідження в Україні 2018 р.. - 2020. - С. 111-112.

Гавінський А. Поселення культури лійчастого посуду у Винниках на горі Лисівка / Гавінський А., Білас Н., М. Рибіцька // Археологічні дослідження в Украӥні 2019 p. - 2020a. - C. 148-149.

Гринчишин Б. Розкопки довкола Винниківського озера / Б. Гринчишин, В. Конопля, В. Сидорович і ін. // Археологічні дослідження в Україні 2018. - 2019. - С. 112 114.

Грищенко В. П. Геологічні пам'ятки природи України: проблеми вивчення, збереження та раціонального використання / В. П. Грищенко, А. А. Іщенко, Ю. О. Русько, В. І. Шевченко. - Київ, 1995. - 60 с. / Препринт НАН України, Центр. наук.- природн. музей; 95-1/.

Коротенко Н. Е. Геологические памятники Украинь : справочник-путеводитель / Н. Е. Коротенко, А. С. Щирица, А. Я. Каневский и др. - Киев : Наукова думка, 1985. - $156 \mathrm{c}$.

Палієнко Е. Природоохоронна геоморфологія в Україні / Е. Палієнко // Українська геоморфологія: стан і перспективи: Матеріали міжнар. наук.-практ. конф. Львів, 1997. - С. 58-60.

Пелещишин М. Розкопки на горі Лисівка у Винниках / М. Пелещишин // Наукові записки Львівського історичного музею. - 1994. - Вип. II-III. - С. 10-15. 
А. Яцишин, Р. Дмитрук, А. Гавінський Природопізнавальні та геоархеологічні маршрути... ISSN 2519-2620. Проблеми геоморфології і палеогеографії...2021. Вип. 1 (12), 155-178

Пелещишин М. Проблеми історії трипільських поселень Західної Волині, межиріччя Західного Бугу та Дністра / М. Пелещишин // Записки наукового товариства Шевченка. - 1998. - Т. ССХXXV. - С. 173-192.

У Львові знайшли унікальні джерела-родичі турецького Памуккале. https://espreso.tv/news/2020/07/22/u_lvovi_znayshly_unikalni_dzherela_quotrodychiq uot_tureckogo_pamukkale

Цись П. Геоморфологія УРСР / П. Цись. - Львів : Вид-во Львів. ун-ту, 1962. - 223 с.

Яцишин А. Елементи геотуристичної мережі Львова / А. Яцишин, Р. Дмитрук // Конструктивна географія і картографія: стан, проблеми, перспективи : матеріали Міжнародної науково-практичної онлайн-конференції, присвяченої 20-річчю кафедри конструктивної географії i картографії Львівського національного університету імені Івана Франка (Україна, м. Львів, 1-3 жовтня 2020 р.). - Львів, 2020. - C. 253-258.

Alexandrowicz W. P. Molluscan assemblages of Late Glacial and Holocene calcareoustufas in Southern Poland / W. P. Alexandrowicz // Folia Quaternaria, 75. - 2004. - P. 1-309.

Diachenko A. Newexcavationsin Vynnyky and the issue of the Funnel Beakerculture Tripolyefrontier / A. Diachenko, M. Rybicka, D. Król, G. Sîrbu (eds.) // Between the East and the West. Dynamic of Social Changes from the Eastern Carpathians to the Dnieper in the 4 th - beginning of $3 \mathrm{rd}$ Millennium BC (Preliminary study). Rzeszów, 2019. - P. 17-30.

Rybicka M. Wstępne informacje o badaniach nad kulturą pucharów lejkowatych w Winnikach, stanowisko Lisiwka koło Lwowa przeprowadzonych w 2016 roku / M. Rybicka, A. Hawinskyj, N. Biłas, D. Król, G. Širbu // Наукові студіï. - 2017. S. 21-38.

\section{REFERENCES}

Bandrivskyi, M. (2003). Poselennia rannozaliznoho viku u Vynnykakh ta problemy zavershalnoho etapu isnuvannia vysotskoi kultury [Settlement of the Early Iron Age in Vynnyky and problems of the final stage of the Vysotsky culture existence]. In Arkheolohichni doslidzhennia Lvivskoho universytetu, 6. Lviv, 204-219. (In Ukrainian).

Bilous, L., Havinskyi, A., Oprysk, V. (2016). Stezhka mytropolyta Andreia Sheptytskoho u Vynnykakh [Metropolitan Andrei Sheptytski path in Vynnyky]. In Lemkivskyi kalendar na 2017 rik, 66, Lviv, 154-159. (In Ukrainian).

Brusak, V., Zinko, Yu. (1995). Heohrafichni doslidzhennia v zapovidnykakh [Geographical researches in reserves]. In Pryrodnychi doslidzhennia na Roztochchi: zb. nauk.-tekhn. prats, Lviv, 5-14. (In Ukrainian).

Brusak, V., Bakun, V. (2011). Metodychni aspekty klasyfikatsii i pasportyzatsii heolohoheomorfolohichnykh pamiatok pryrody [Methodological aspects of classification and certification of geological and geomorphological monuments of nature]. In Visnyk Lvivskoho universytetu. Seriia heohrafichna, 39. 44-51. (In Ukrainian). 
А. Яцишин, Р. Дмитрук, А. Гавінський Природопізнавальні та геоархеологічні маршрути... ISSN 2519-2620. Проблеми геоморфології і палеогеографії...2021. Вип. 1 (12), 155-178

Verteletskyi, D., Bilas, N., Havinskyi, A., Rybitska, M. (2020). Rozkopky na hori Zhupan u m. Vynnyky [Excavations on Zhupan Mount in Vynnyky]. In Arkheolohichni doslidzhennia v Ukraini 2019, 146-147. (In Ukrainian).

Voloshin, P. (1989). Harakteristika prirodnyih usloviy g. Lvova [Characteristics of natural conditions of Lviv]. In Razdel k genplanu goroda Lvova, 1. (In Russian).

Voloshyn, P. (2009). Metodychni rekomendatsii z heoloho-heomorfolohichnoho rozdilu zahalnoekolohichnoi praktyky (dlia studentiv druhoho kursu heohrafichnoho fakultetu spetsialnosti "Ekolohiia, okhorona navkolyshnoho seredovyshcha ta zbalansovane pryrodokorystuvannia") [Methodological recommendations from the geologicalgeomorphological section of the general ecological practice (for second-year students of the Faculty of Geography, majoring in "Ecology, environmental protection and sustainable nature management")]. Lviv: VC Ivan Franko National University of Lviv. (In Ukrainian).

Havinskyi, A., Bilas, N., Hrynchyshyn, B. (2015). Rozkopky u Vynnykakh na hori Shypshyna [Excavations in Vynnyky on Shypshyna Mount]. In Arkheolohichni doslidzhennia v Ukraini 2013 r., 121-122. (In Ukrainian).

Havinskyi, A., Bandrivskyi, M., Oprysk, V. (2016). Riativni rozkopky u Vynnykakh bilia Lvova [Rescue excavations in Vynnyky near Lviv]. In Arkheolohichni doslidzhennia $v$ Ukraini 2015 r., 92-93. (In Ukrainian).

Havinskyi, A., Bilas, N., Rybitska, M. (2020) Rozkopky poselennia kultury liichastoho posudu Vynnyky-Lysivka u 2017-2018 rr. [Excavations of the Vynnyky-Lysivka funnel-shaped culture settlement in 2017-2018]. In Arkheolohichni doslidzhennia $v$ Ukraini 2018 r., 111-112. (In Ukrainian).

Havinskyi, A., Bilas, N., Rybitska, M. (2020a). Poselennia kultury liichastoho posudu u Vynnykakh na hori Lysivka [Settlement of funnel-shaped pottery culture in Vynnyky on Lysivka Mount]. In Arkheolohichni doslidzhennia v Ukraini 2019 r., 148-149. (In Ukrainian).

Hrynchyshyn, B., Konoplia, V., Sydorovych, V. i in. (2019). Rozkopky dovkola Vynnykivskoho ozera [Excavations around Vynnykivske Lake]. In Arkheolohichni doslidzhennia v Ukraini 2018 r., 112-114. (In Ukrainian).

Hryshchenko, V., Ishchenko, A., Rusko, Yu., Shevchenko, V. (1995). Heolohichni pamiatky pryrody Ukrainy: problemy vyvchennia, zberezhennia ta ratsionalnoho vykorystannia [Geological monuments of nature of Ukraine: problems of study, preservation and sustainable management]. Kyiv, NAN Ukrainy. (In Ukrainian).

Korotenko, N. E., Schiritsa, A. S., Kanevskiyi, A. Ya. i dr. (1985). Geologicheskie pamyatniki Ukrainyi: spravochnik-putevoditel [Geological monuments of Ukraine: a guide]. Kiev :Naukova dumka. (In Ukrainian).

Paliienko, E. (1994). Pryrodookhoronna heomorfolohiia v Ukraini [Environmental geomorphology in Ukraine]. In Ukrainska heomorfolohiia: stan i perspektyvy: Materialy mizhnar. nauk.-prakt. konf. 2009. Lviv, Ukraine. (In Ukrainian).

Peleshchyshyn, M. (1994) Rozkopky na hori Lysivka u Vynnykakh [Excavations on Lysivka Mount in Vynnyky]. In Naukovi zapysky Lvivskoho istorychnoho muzeiu, 2-3, 10-15. (In Ukrainian). 
А. Яцишин, Р. Дмитрук, А. Гавінський Природопізнавальні та геоархеологічні маршрути... ISSN 2519-2620. Проблеми геоморфології і палеогеографії..2021. Вип. 1 (12), 155-178

Peleshchyshyn, M. (1998). Problemy istorii trypilskykh poselen Zakhidnoi Volyni, mezhyrichchia Zakhidnoho Buhu ta Dnistra [Problems of the history of Trypillia settlements of Western Volhynia, the interfluve of the Western Bug and the Dniester]. In Zapysky naukovoho tovarystva Shevchenka, SSXXXV, 173-192. (In Ukrainian).

U Lvovi znaishly unikalni dzherela-rodychi turetskoho Pamukkale. [Unique relatives of Turkish Pamukkale were found in Lviv]. (2020). https://espreso.tv/news/2020/07/22/u lvovi znayshly unikalni dzherela quotrodychiq uot tureckogo Pamukkale (In Ukrainian).

Tsys, P. (1962). Heomorfolohiia URSR [Geomorphology of the USSR]. Lviv : Vyd-vo Lviv. un-tu. (In Ukrainian).

Yatsyshyn, A., Dmytruk, R. (2020). Elementy heoturystychnoi merezhi Lvova [Elements of the geotourism network of Lviv]. In Konstruktyvna heohrafiia i kartohrafiia: stan, problemy, perspektyvy: materialy Mizhnarodnoi naukovo-praktychnoi onlainkonferentsii, prysviachenoi 20-richchiu kafedry konstruktyvnoi heohrafii i kartohrafii Lvivskoho natsionalnoho universytetu imeni Ivana Franka (Ukraina, m. Lviv, 1-3 zhovtnia 2020 r.). Lviv, Ukraine. (In Ukrainian).

Alexandrowicz, W. P. (2004). Molluscan assemblages of Late Glacial and Holocene calcareoustufas in Southern Poland. In Folia Quaternaria, 75, 1-309.

Diachenko, A., Rybicka, M., Król, D., Sîrbu, G. (eds.) (2019). Newex cavationsin Vynnyky and the issue of the Funnel Beakerculture - Tripolyefrontier In Between the East and the West. Dynamic of Social Changes from the Eastern Carpathians to the Dnieper in the 4 th - beginning of 3 rd Millennium BC (Preliminary study). Rzeszów.

Rybicka, M., Hawinskyj, A., Biłas, N., Król, D., Širbu, G. (2017). Wstępne informacje o badaniach nad kulturą pucharów lejkowatych w Winnikach, stanowisko Lisiwka koło Lwowa przeprowadzonych w 2016 roku [Introductory information about the study of the culture of funnel-shaped pottery in Vynnyky, Lysivka man site near Lviv, conducted in 2016]. In Research studies, 21-38. 